\title{
Penerapan pembelajaran model STAD (Student Team Achievement Division) untuk Meningkatkan Prestasi Belajar Matematika Siswa di SDN 39 Cakranegara
}

\author{
Joni Lazarus \\ SDN 39 Cakranegara, Kota Mataram \\ Corresponding Author. Email: jonilazarus@gmail.com
}

\begin{abstract}
This study aims to improve students' mathematics learning achievement through the application of STAD model learning. This research method uses a classroom action research method with research subjects namely fifth grade students of SD Negeri 39 Cakranegara. The research instrument used observation and tests. The data analysis technique used in this research was qualitative and quantitative descriptive analysis. The results of this study indicate that the application of the STAD (Student Team Achievement Division) model of learning in building materials in class V SDN 39 Cakranegara is proven to improve student learning outcomes, this can be seen from the acquisition of class average scores from student test results at each stage The cycle is increasing, namely, the class average value in pre-cycle is 50 , in cycle I is 60.70 and in cycle II is 75.35 .
\end{abstract}

\begin{abstract}
Abstrak: Penelitian ini bertujuan untuk meningkatkan prestasi belajar matematika siswa melalui penerapan pembelajaran model STAD. Metode penelitian ini menggunakan metode penelitian tindakan kelas dengan subjek penelitian yakni siswa kelas V SD Negeri 39 Cakranegara. Instrumen penelitian ini menggunakan observasi, dan tes. Teknik analisis data penelitian ini menggunakan analisis deskriptif kualitatif dan kuantitatif. Hasil penelitian ini menunjukkan bahwa penerapan pembelajaran model STAD (Student Team Achievement Division) dalam materi bangun ruang di kelas V SDN 39 Cakranegara terbukti dapat meningkatkan hasil belajar siswa, hal ini dapat terlihat dari perolehan nilai rata-rata kelas dari hasil tes siswa pada setiap tahapan siklus semakin meningkat yaitu, nilai rata-rata kelas pada prasiklus sebesar 50, pada siklus I sebesar 60,70 dan pada siklus II sebesar 75,35.
\end{abstract}

Key Words:

STAD, Learning

Achievement,

Mathematics.

Kata Kunci:

Model STAD, Prestasi

Belajar, Matematika.

How to Cite: Lazarus, J. (2020). Penerapan pembelajaran model STAD (Student Team Achievement Division) untuk Meningkatkan Prestasi Belajar Matematika Siswa di SDN 39 Cakranegara. Jurnal Teknologi Pendidikan, 5(2), 132-143. Retrieved from http://ojs.ikipmataram.ac.id/index.php/jtp/article/view/3059

\section{Pendahuluan}

Saat ini pengetahuan dan teknologi mengalami perkembangan yang sangat pesat. Manusia dengansegala persoalan dan kegiatannya secara dinamis dituntut mampu beradaptasi dan memecahkan segala persoalan yang sudah dihadapi saat ini. Tentunya dalam memecahkan segala persoalan dibutuhkan kecerdasan, kreativitas, dan kearifan agar dalam menyelesaikan masalah tidak menimbulkan masalah yang lebih sulit. Untuk menciptakan manusia yang berkualitas tentu tidak terlepas dari dunia pendidikan. Karena pendidikanmerupakan salah satu wadah untuk melahirkan generasi yang berkualitas dan mandiri. Oleh karena itu, pendidikan dituntut memiliki kualitas yang baik.

Perbaikan mutu pendidikan dan pengajaran senantiasa harus tetap diupayakan dan dilaksanakan dengan jalan meningkatkan kualitas pembelajaran. Melalui peningkatan kualitas pembelajaran, siswa akan semakin termotivasi dan belajar, daya kreativitasnya akan semakin meningkat, semakin positif sikapnya, semakin bertambah jenis pengetahuan dan keterampilan yang dikuasai, dan semakin mantap pemahaman terhadap materi yang dipelajari. 
Sebagai upaya peningkatan mutu pendidikan secara nasional, telah dilakukan pengkajian ulang terhadap kurikulum. Sehingga terjadi penyempurnaan kurikulum dari waktu ke waktu. Salah satunya dengan KTSP (Kurikulum Tingkat Satuan Pendidikan), yang proses pembelajarannya menekankan pada pemberian pengalaman secara langsung untuk mengembangkan kompetensi agar menjelajahi dan memahami alam sekitar secara ilmiah.

Sesuai dengan Undang-Undang nomor 20 tahun 2003 tentang Sistem Pendidikan Nasional, pendidikan nasional bertujuan untuk berkembangnya potensi peserta didik agar menjadi manusia yang beriman dan bertaqwa kepada Tuhan Yang Maha Esa, berakhlak mulia, sehat, berilmu, cakap, kreatif, mandiri, dan menjadi warga negara yang demokratis serta bertanggung jawab (Anwar Arifin: 2003). Tujuan di atas dapat dicapai salah satunya melalui proses pembelajaran matematika. Tujuan pembelajaran matematika menurut Kurikulum 2006 (KTSP) adalah agar peserta didik memiliki kemampuan sebagai berikut (Depdiknas, 2006)

1) Memahami konsep matematika, menjelaskan keterkaitan antar konsep dan mengaplikasikan konsep algoritma, secara luwes, akurat, efisien, dan tepat, dalam pemecahan masalah.

2) Menggunakan penalaran pada pola dan sifat, melakukan manipulasi matematika dalam membuat generalisasi, menyusun bukti, atau menjelaskan gagasan dan pernyataan matematika.

3) Memecahkan masalah yang meliputi kemampuan memahami masalah, merancang model matematika, menyelesaikan model dan menafsirkan solusi yang diperoleh.

4) Mengomunikasikan gagasan dengan simbol, tabel, diagram, atau media lain untuk menjelaskan keadaan atau masalah.

5) Memiliki sikap menghargai kegunaan matematika dalam kehidupan, yaitu memiliki rasa ingin tahu, perhatian, dan minat dalam mempelajari matematika, serta sikap ulet dan percaya diri dalam pemecahan masalah.

Oleh karena itu, kegiatan pembelajaran matematika yang dilakukan harus selalu mengacu pada tujuan diatas dengan memperhatikan karakteristik siswa sebagai pembelajar.

Matematika sekolah itu bagian dari matematika yang dipilih antara lain dengan berorientasi pada kependidikan. Dengan demikian dalam pembelajaran matematika perlu diusahakan sesuai dengan kemampuan kognitif siswa, mengkonkritkan objek matematika yang abstrak menjadi mudah dipahami siswa. Hal ini disebabkan anak seusia Sekolah Dasar masih dalam pola berpikir kongkrit, yaitu berpikir yang didasari oleh manipulasi fisik dari objek-objek atau benda-benda konkrit (Piaget dalam Surya, 2007). Dalam hubungannya dengan pembelajaran matematika, teori Piaget mengacu kepada kegiatan pembelajaran yang harus melibatkan partisipasi peserta didik. Sehingga menurut teori ini pengetahuan tidak hanya sekedar dipindahkan secara verbal tetapi harus dikonstruksi dan direkonstruksi peserta didik. Sebagai realisasi teori ini, maka dalam kegiatan pembelajaran peserta didik haruslah bersifat aktif.

Dalam setiap kesempatan, pembelajaran matematika hendaknya dimulai dengan pengenalan masalah yang sesuai situasi (contextual problem). Dengan mengajukan masalah kontekstual, peserta didik secara bertahap dibimbing untuk menguasai konsep matematika. Untuk meningkatkan keefektifan pembelajaran, sekolah diharapkan menggunakan teknologi informasi dan komunikasi seperti computer, alat peraga, atau media lainnya (Depdiknas, 2008).

Agar proses belajar dapat berlangsung dengan efektif para guru hendaknya memperhatikan faktor-faktor sebagai berikut (Mohamad Surya, 2006): 1) Penjabaran tujuan; 
2) Memotivasi kepada siswa; 3) Penggunaan model; 4) Urutan materi; 5) Bantuan dalam usaha pertama; 6) Pengaturan latihan secara efektif; 7) Masalah perbedaan individu; 8) Evaluasi dan bimbingan; 9) Usaha menghafal; 10) Bantuan dalam aplikasi hasil belajar.

Siswa di Sekolah Dasar (SD) khususnya kelas V masih banyak yang mengalami kesulitan dalam belajar perkalian dan pembagian. Hal ini bertentangan dengan tujuan pembelajaran matematika di Sekolah Dasar yang lebih mengutamakan siswa dapat memahami,mengenal serta mahir menggunakan bilangan dalam kaitannya dengan prakteknya dalam kehidupan sehari-hari.(Ruseffendi, 1988).

Berdasarkan hasil analisis terhadap nilai ulangan harian mata pelajaran matematika terutama dalam standar kompetensi Geometri dan Pengukuran yaitu memahami sifat bangun ruang sederhana seta menghitung volume bangun ruang tersebut pada siswa Kelas V di SDN 39 Cakranegara didapat bahwa prestasi belajar matematika siswa masih rendah. Fakta di atas menunjukkan bahwa sebagian besar siswa masih mengalami kesulitan dalam memahami mata pelajaran matematika. Hal ini mungkin disebabkan oleh pendekatan, strategi, model, atau metode yang diterapkan oleh guru kurang sesuai, juga kemampuan guru serta sarana pembelajaran yang meliputi media, alat peraga, dan buku pegangan siswa yang terbatas, atau sebab lain yang tidak diketahui. Oleh sebab itu penggunaan metode pembelajaran dirasa sangat penting untuk membantu siswa dalam memahami konsep-konsep matematika.

Model pembelajaran kooperatif banyak mengilhami lahirnya model-model pembelajaran mutakhir yang berpusat pada siswa. Pembelajaran kooperatif berasal dari kata "kooperatif" yang artinya mengerjakan sesuatu secara bersama-sama dengan saling membantu satu sama lainnya sebagai satu kelompok atau satu tim. Slavin mengemukakan bahwa pembelajaran kooperatif adalah suatu model pembelajaran dimana sistem belajar dan bekerja dalam kelompok-kelompok kecil yang berjumlah 4-6 orang secara kolaboratif sehingga dapat merangsang siswa lebih bergairah dalam belajar (Isjoni, 2009). Menurut Johnson \& Johnson pembelajaran kooperatif mengandung arti bekerja bersama dalam mencapai tujuan bersama. Pembelajaran kooperatif adalah mengelompokkan siswa di dalam kelas ke dalam suatu kelompok kecil agar siswa dapat bekerja sama dengan kemampuan maksimal yang mereka miliki dan mempelajari satu sama lain dalam kelompok tersebut (Isjoni, 2009).

Metode pembelajaran jenisnya beragam yang masing-masing memiliki kelebihan dan kelemahan, maka pemilihan metode yang sesuai dengan topik atau pokok bahasan yang akan diajarkan harus betul-betul dipikirkan oleh guru yang akan menyampaikan materi pelajaran. Sedangkan penggunaan metode STAD diharapkan dapat meningkatkan aktivitas siswa dalam proses belajar mengajar sehingga dalam proses belajar mengajar itu aktivitasnya tidak hanya didominasi oleh guru, dengan demikian siswa akan terlibat secara fisik, emosional dan intelektual yang pada gilirannya diharapkan konsep perubahan benda yang diajarkan oleh guru dapat dipahami oleh siswa. Adapun tujuan penelitian ini adalah untuk meningkatkan prestasi belajar matematika melalui penerapan pembelajaran model STAD (Student Team Achievement Division) pada siswa kelas V SDN 39 Cakranegara.

\section{Metode Penelitian}

Penelitian ini merupakan Penelitian Tindakan Kelas (Classroom Action Research) yang dilaksanakan di kelas V SD Negeri 39 Cakranegara untuk mata pelajaran Matematika. Materi pembelajaran yang digunakan dalam penelitian ini adalahBangun Ruang. Subjek Penelitian Tindakan Kelas ini adalah siswa kelas V SDN 39 Cakranegara,dengan jumlah siswa 28 orang, terdiri dari 15 siswa putra dan 12 siswa putri dan Peneliti adalah guru di SDN 
39 Cakranegara berkolaborasi dengan guru kelas yang lain di SDN 39 Cakranegara. Penelitian tindakan kelas ini dilakukan 2 siklus berdasarkan materi dibagi dua, yaitu Memahami Sifat dan Jaring-Jaring Bangun Ruang Sederhana serta Menghitung Volume Kubus dan Balok.

Pengumpulan data dalam penelitian ini sangat diperlukan. Data yang akurat sangat membantu dalam melakukan tindakan dan pengambilan kesimpulan. Data yang dijaring adalah data awal dan data pada saat pelaksanaan penelitian. Untuk keperluan itu diperlukan instrumen antara lain (1) lembar pengamatan untuk guru; (2) lembar pengamatan untuk siswa; (3) angket tanggapan siswa; (4) format catatan lapangan; (5) lembar kerja siswa; (6) lembar soal tes akhir siklus. Analisis Data yang telah terkumpul menggunakan analisis deskriptif memaparkan hasil pengamatan, dan hasil angket pada setiap akhir siklus dengan membandingkan hasil yang dicapai tiap siklus dan tabulasi sederhana secara kuantitatif. Penelitian ini dinyatakan berhasil, jika mencapai indikator yang sudah ditetapkan oleh peneliti sebagai berikut: (1) Rata-rata kelas sekurang-kurangnya mencapai nilai 60; (2) Adanya peningkatan nilai rata-rata kelas dari tindakan awal sampai tindakan akhir; (3) Sekurang-kurangnya ada 85\% siswa dalam kelas yang mencapai KKM (Kriteria Ketuntasan Minimal). KKM pada materi ini adalah 65 (enam puluh lima).

\section{Hasil Penelitian dan Pembahasan \\ Deskripsi Hasil Perbaikan Pembelajaran}

Hasil penelitian yang dilakukan pada siswa kelas V SD Negeri 39 Cakranegara terkait hasil belajar Matematika tentang bangun ruang. melalui metode Pembelajaran Model STAD (Student Team Achievement Division), yang dilaksanakan dalam perbaikan pembelajaran pada siklus I dan siklus II secara lengkap dijabarkan sebagai berikut.

\section{Pra Siklus}

Pembelajaran pra siklus mata pelajaran Matematika kelas V SD Negeri 39 Cakranegara dengan materi pokok meningkatkan hasil belajar matematika materi bangun ruang melalui metode Pembelajaran Model STAD (Student Team Achievement Division),. Hasil pembelajaran pra siklus disajikan dalam tabel 1 sebagai berikut.

Tabel 1. Hasil Evaluasi Pra Siklus

\begin{tabular}{|c|l|c|c|c|}
\hline No & \multicolumn{1}{|c|}{ Nama Siswa } & Nilai & Tuntas & $\begin{array}{c}\text { Belum } \\
\text { Tuntas }\end{array}$ \\
\hline 1 & Aditya Dimas Pratama & 40 & & $\sqrt{ }$ \\
\hline 2 & Ahmad sapri & 30 & & $\sqrt{ }$ \\
\hline 3 & Ardi Firmansyah & 40 & & $\sqrt{ }$ \\
\hline 4 & Baiq asmaul Jannah & 50 & & $\sqrt{ }$ \\
\hline 5 & Baiq Lilik Maryanti & 50 & & $\sqrt{ }$ \\
\hline 6 & Baiq Sinta Handa L. & 40 & & $\sqrt{ }$ \\
\hline 7 & Dahlia Kurratunaini & 50 & & $\sqrt{ }$ \\
\hline 8 & Fathir Laela Hamid & 60 & & $\sqrt{ }$ \\
\hline 9 & Hayatul Amelia & 70 & $\sqrt{ }$ & $\sqrt{ }$ \\
\hline 10 & Laili Salma Izzati & 40 & & $\sqrt{ }$ \\
\hline 11 & Lalu Ardana Farhan H. & 50 & & $\sqrt{ }$ \\
\hline 12 & M. Alfin Izhar & 50 & & $\sqrt{ }$ \\
\hline 13 & M. Arif Wijaya & 60 & & $\sqrt{ }$ \\
\hline 14 & Mira Yuniarti & 70 & $\sqrt{ }$ & \\
\hline
\end{tabular}




\begin{tabular}{|l|l|c|c|c|}
\hline 15 & Muh. IfanKahrul A. & 50 & & $\sqrt{ }$ \\
\hline 16 & Nadila Afrilia Utami & 50 & & $\sqrt{ }$ \\
\hline 17 & Nandana Tenden K.P & 40 & & $\sqrt{ }$ \\
\hline 18 & Nazwa Afrilia Soleha & 30 & & $\sqrt{ }$ \\
\hline 19 & Rafli Ahmad & 40 & & $\sqrt{ }$ \\
\hline 20 & Rido Afrianyah & 50 & & $\sqrt{ }$ \\
\hline 21 & Rifal Afrian & 60 & & $\sqrt{ }$ \\
\hline 22 & Rudi Awam & 70 & $\sqrt{ }$ & $\sqrt{ }$ \\
\hline 23 & Siti Fatila Rasani & 50 & & $\sqrt{ }$ \\
\hline 24 & Sofia Nusa Fitri & 40 & & $\sqrt{ }$ \\
\hline 25 & Syania Rizki Maulida & 40 & & $\sqrt{ }$ \\
\hline 26 & Teguh Apita Hadi & 60 & & \\
\hline 27 & Titania Arum Dafta & 50 & & $\sqrt{ }$ \\
\hline 28 & Yustian Alfigo & 70 & $\sqrt{ }$ \\
\hline \multicolumn{7}{|c|}{ Jumlah } & $\mathbf{1 3 9 0}$ & $\mathbf{5 0}$ & & \\
\hline
\end{tabular}

Nilai hasil tes formatif diperoleh setelah proses pembelajaran selesai. Guru memberi evaluasi untuk mengetahui tingkat penguasaan materi yang telah diajarkan pada pembelajaran pra siklus. Adapun langkah-langkah pelaksanaan pra siklus yaitu :

\section{Perencanaan}

Membuat rencana pembelajaran, membuat lembar pengamatan, menyediakan alat peraga, membuat evaluasi, membuat lembar kerja dan menentukan teman sejawat yang akan mengobservasi aktivitas siswa dan guru selama kegiatan pembelajaran.

\section{Pelaksanaan}

Pelaksanaan pembelajaran awal dilakukan selama dalam proses pembelajaran kelas V SD Negeri 39 Cakranegara. Dengan menggunakan instrument penelitian. Supervisor 2 melakukan pengamatan terhadap tingkahlaku guru dalam menyampaikan materi melalui metode Pembelajaran Model STAD (Student Team Achievement Division). Tahap pelaksanaan pembelajaran dilaksanakan seperti langkah-langkah di bawah ini :

1) Guru melakukan apersepsi melalui tanya jawab

2) Guru menyampaikan motifasi dan tujuan pembelajaran.

3) Siawa melakukan pembagian Kelompok

4) Siswa mengerjakan lembar kerja secara kelompok.

5) Perwakilan siswa maju membacakan hasil kerja kelompok.

6) Siswa menanggapi hasil kerja tiap kelompok dengan dipandu oleh guru.

7) Siswa bersama guru menyimpulkan materi pelajaran.

8) Siswa mengerjakan tes formatif.

9) Guru mengoreksi hasil tes formatif.

10) Guru memberikan tindak lanjut berupa soal perbaikan dan pengayaan dalam bentuk pekerjaan rumah.

\section{Pengamatan}

Dari hasil pengamatan yang diperoleh oleh peneliti yang dibantu oleh teman sejawat sebagai observer. Berikut hasil pengamatan pada waktu proses pembelajaran pada pra siklus. Pada pra siklus ini pembelajaran berlangsung, siswa belum aktif dalam pembelajaran, siswa pada waktu diskusi kelompok belum bisa bekerja sama, waktu diberi penjelasan oleh guru ada siswa yang bermain sendiri. Sedangkan hasil pengamatan terhadap guru yaitu guru kurang 
menguasai materi, guru belum bisa mengontrol keaktifan siswa, guru belum menggunakan alat peraga, sehingga siswa kurang memahami struktur daun dan fungsinya.

\section{Refleksi}

Dari hasil refleksi yang dilakukan oleh guru melalui diskusi dengan teman sejawat sebagai observer diperoleh beberapa kekurangan selama proses pembelajaran. Sebelum pelajaran dimulai guru tidak mengkondisikan siswa untuk menerima pelajaran, sehingga siswa belum siap menerima pelajaran. Pada waktu pemberian materi guru hanya ceramah, sehingga siswa hanya mengGrafikkan materi bangun ruangitu seperti apa. Dari refleksi itu guru menyadari kekurangannya dalam proses pembelajaran oleh karena itu guru akan memperbaikinya pada perbaikan pembelajaran siklus berikutnya.

1) Keberhasilan

a. Siswa merasa senang dengan pembelajaran dengan mempelajari bangun ruang

b. Guru dapat belajar untuk menerapkan alat peraga pembelajaran.

c. Guru dapat menjadikan alat peraga sebagai variasi model pembelajaran.

2) Kegagalan

\section{Deskripsi Siklus I}

a. Masih ada 24 siswa yang belum mencapai tingkat ketuntasan minimal.

b. Ada beberapa siswa yang belum bisa memahami materi.

c. Dalam menyimpulkan materi guru masih belum melibatkan siswa.

Pelaksanaan pembelajaran siklus I dengan subjek siswa kelas V SD Negeri 39 Cakranegara dengan dibantu oleh teman sejawat yang bertindak sebagai observer, peneliti melaksanakan sesuai rencana. Skenario pembelajaran berlangsung dengan baik. Peneliti melaksanakan sesuai rencana. Pada akhir pembelajaran peneliti mengadakan evaluasi hasil belajar untuk mengetahui tingkat keberhasilan. Hasil perbaikan pembelajaran siklus I disajikan dalam tabel sebagai berikut.

Tabel 2. Hasil Siklus I

\begin{tabular}{|c|l|c|c|c|}
\hline No & \multicolumn{1}{|c|}{ Nama Siswa } & Nilai & Tuntas & $\begin{array}{c}\text { Belum } \\
\text { Tuntas }\end{array}$ \\
\hline 1 & Aditya Dimas Pratama & 70 & $\sqrt{ }$ & \\
\hline 2 & Ahmad sapri & 60 & & $\sqrt{ }$ \\
\hline 3 & Ardi Firmansyah & 80 & $\sqrt{ }$ & \\
\hline 4 & Baiq asmaul Jannah & 70 & $\sqrt{ }$ & \\
\hline 5 & Baiq Lilik Maryanti & 70 & $\sqrt{ }$ & \\
\hline 6 & Baiq Sinta Handa L. & 60 & & $\sqrt{ }$ \\
\hline 7 & Dahlia Kurratunaini & 80 & $\sqrt{ }$ & \\
\hline 8 & Fathir Laela Hamid & 80 & $\sqrt{ }$ & \\
\hline 9 & Hayatul Amelia & 90 & $\sqrt{ }$ & \\
\hline 10 & Laili Salma Izzati & 70 & $\sqrt{ }$ & \\
\hline 11 & Lalu Ardana Farhan H. & 70 & $\sqrt{ }$ & \\
\hline 12 & M. Alfin Izhar & 70 & $\sqrt{ }$ & \\
\hline 13 & M. Arif Wijaya & 80 & $\sqrt{ }$ & \\
\hline 14 & Mira Yuniarti & 90 & $\sqrt{ }$ & \\
\hline 15 & Muh. IfanKahrul A. & 70 & $\sqrt{ }$ & \\
\hline 16 & Nadila Afrilia Utami & 80 & $\sqrt{ }$ & \\
\hline 17 & Nandana Tenden K.P & 60 & & $\sqrt{ }$ \\
\hline 18 & Nazwa Afrilia Soleha & 70 & $\sqrt{ }$ & \\
\hline
\end{tabular}




\begin{tabular}{|l|l|c|c|l|}
\hline 19 & Rafli Ahmad & 70 & $\sqrt{ }$ & \\
\hline 20 & Rido Afrianyah & 80 & $\sqrt{ }$ & \\
\hline 21 & Rifal Afrian & 80 & $\sqrt{ }$ & \\
\hline 22 & Rudi Awam & 90 & $\sqrt{ }$ & \\
\hline 23 & Siti Fatila Rasani & 80 & $\sqrt{ }$ & \\
\hline 24 & Sofia Nusa Fitri & 70 & $\sqrt{ }$ & \\
\hline 25 & Syania Rizki Maulida & 70 & $\sqrt{ }$ & \\
\hline 26 & Teguh Apita Hadi & 80 & $\sqrt{ }$ & \\
\hline 27 & Titania Arum Dafta & 90 & $\sqrt{ }$ & \\
\hline 28 & Yustian Alfigo & 80 & $\sqrt{ }$ & \\
\hline \multicolumn{7}{c}{ Jumlah } & $\mathbf{2 1 1 0}$ & & \\
\hline \multicolumn{7}{|c|}{ Rata-rata } & $\mathbf{7 5 . 3 5}$ & & \\
\hline
\end{tabular}

Hasil evaluasi siklus I diperoleh setelah pelaksanaan pembelajaran siklus I selesai. Dalam pembelajaran siklus I melalui langkah-langkah berikut.

\section{Perencanaan}

Menyusun rencana pembelajaran dengan tujuan perbaikan siklus I, Memilih metode siklus I, Mempersiapkan LKS yang akan digunakan dalam perbaikan pembelajaran, Membuat dan merancang lembar observasi aktivitas guru beserta indikatornya.

\section{Pelaksanaan}

Pelaksanaan pembelajaran siklus I dilaksanakan dikelas V. Kegiatan belajar mengajar sesuai dengan apa yang tertulis dalam rencana pelaksanaan pembelajaran.

\section{Pengamatan}

Pada tahap ini pengamat mencatat apa yang telah terjadi pada pembelajaran perbaikan siklus I dengan menggunakan lembar observasi. Dalam proses ini diperoleh data bahwa :

\section{Refleksi}

$\checkmark$ Penjelasan materi sangat cepat sehingga kurang dipahami siswa

$\checkmark$ Kurang memberikan kesempatan pada anak untuk bertanya

$\checkmark$ Perhatian guru pada siswa masih kurang.

Hasil dari observasi / pengamatan dikumpulkan dan dianalisis. Dari hasil observasi guru mengadakan refleksi untuk mengetahui kekurangan, hambatan dan kendala yang terjadi pada proses pembelajaran. Dengan dasar hasil tes formatif yang menunjukkan menunjukkan peningkatan pada pembelajaran sebelumnya, namun untuk mencapai ketuntasan $75 \%$ belum tercapai. Maka penulis mengadakan perbaikan pembelajaran tahap berikutnya yang menjadi fokus perbaikan adalah sebagai berrikut.

1) Memberikan materi yang jelas dan lengkap sehingga mudah dipahami siswa.

2) Memberikan kesempatan pada siswa untuk bertanya.

3) Menggunakan model pembelajaran yang tepat.

Keberhasilan dan kegagalan pada siklus I antara lain:

1) Keberhasilan

a) Hasil evaluasi belajar siswa meningkat.

b) Sebagian besar siswa sudah memahami materi.

c) Siswa sudah berani maju mengerjakan soal.

d) Siswa sudah berani untuk mengajukan pertanyaan.

2) Kegagalan

a) Masih ada 20 siswa yang belum mencapai tingkat ketuntasan.

b) Kurang memberikan kesempatan pada anak untuk bertanya. 


\section{Deskripsi Siklus II}

c) Penggunaan alat peraga kurang maksimal.

d) Masih ada beberapa siswa yang pada saat pelajaran berlangsung masih belum bisa terlibat aktif.

Perbaikan pembelajaran siklus II dilaksanakan dengan dibantu oleh teman sejawat yang bertindak sebagai observer, peneliti melaksanakan sesuai rencana. Skenario pembelajaran berlangsung dengan baik. Peneliti melaksanakan sesuai rencana. Pada akhir pembelajaran peneliti mengadakan evaluasi hasil belajar untuk mengetahui tingkat keberhasilan.Hasil perbaikan pembelajaran siklus II disajikan dalam tabel sebagai berikut.

Tabel 3. Hasil Evaluasi Perbaikan Pembelajaran Siklus II

\begin{tabular}{|c|l|c|c|c|}
\hline No & \multicolumn{1}{|c|}{ Nama Siswa } & Nilai & Tuntas & $\begin{array}{c}\text { Belum } \\
\text { Tuntas }\end{array}$ \\
\hline 1 & Aditya Dimas Pratama & 70 & $\sqrt{ }$ & \\
\hline 2 & Ahmad sapri & 60 & & $\sqrt{ }$ \\
\hline 3 & Ardi Firmansyah & 80 & $\sqrt{ }$ & \\
\hline 4 & Baiq asmaul Jannah & 70 & $\sqrt{ }$ & \\
\hline 5 & Baiq Lilik Maryanti & 70 & $\sqrt{ }$ & \\
\hline 6 & Baiq Sinta Handa L. & 60 & & $\sqrt{ }$ \\
\hline 7 & Dahlia Kurratunaini & 80 & $\sqrt{ }$ & \\
\hline 8 & Fathir Laela Hamid & 80 & $\sqrt{ }$ & \\
\hline 9 & Hayatul Amelia & 90 & $\sqrt{ }$ & \\
\hline 10 & Laili Salma Izzati & 70 & $\sqrt{ }$ & \\
\hline 11 & Lalu Ardana Farhan H. & 70 & $\sqrt{ }$ & \\
\hline 12 & M. Alfin Izhar & 70 & $\sqrt{ }$ & \\
\hline 13 & M. Arif Wijaya & 80 & $\sqrt{ }$ & \\
\hline 14 & Mira Yuniarti & 90 & $\sqrt{ }$ & \\
\hline 15 & Muh. IfanKahrul A. & 70 & $\sqrt{ }$ & \\
\hline 16 & Nadila Afrilia Utami & 80 & $\sqrt{ }$ & \\
\hline 17 & Nandana Tenden K.P & 60 & & $\checkmark$ \\
\hline 18 & Nazwa Afrilia Soleha & 70 & $\sqrt{ }$ & \\
\hline 19 & Rafli Ahmad & 70 & $\sqrt{ }$ & \\
\hline 20 & Rido Afrianyah & 80 & $\sqrt{ }$ & \\
\hline 21 & Rifal Afrian & 80 & $\sqrt{ }$ & \\
\hline 22 & Rudi Awam & 90 & $\sqrt{ }$ & \\
\hline 23 & Siti Fatila Rasani & 80 & $\sqrt{ }$ & \\
\hline 24 & Sofia Nusa Fitri & 70 & $\sqrt{ }$ & \\
\hline 25 & Syania Rizki Maulida & 70 & $\sqrt{ }$ & \\
\hline 26 & Teguh Apita Hadi & 80 & $\sqrt{ }$ & \\
\hline 27 & Titania Arum Dafta & 90 & $\sqrt{ }$ & \\
\hline 28 & Yustian Alfigo & 80 & $\sqrt{ }$ & \\
\hline & \multicolumn{1}{|l|}{ Jumlah } & $\mathbf{2 1 1 0}$ & & \\
\hline & Rata-rata & $\mathbf{7 5 . 3 5}$ & & \\
\hline
\end{tabular}

Berikut ini adalah langkah-langkah pelaksanaan perbaikan pembelajaran siklus II :

Perencanaan 
Menyusun rencana pembelajaran, menentukan alat peraga, menentukan metode pembelajaran, merencanakan fokus perbaikan pembelajaran, menyusun lembar observasi, menyusun lembar evaluasi.

\section{Pelaksanaan}

1) Guru memberitahu siswa bahwa hari ini siswa akan belajar melalui permainan teka teki silang (TTS).

2) Setelah memberitahu tentang permainan TTS, guru meminta siswa untuk membagi menjadi dua kelompok.

3) Guru mengajak siswa untuk membuat peraturan permainan TTS.

4) Siswa secara bersama-sama membuat peraturan permainan TTS.

5) Siswa menggunakan koin untuk menentukan kelompok mana yang memulai permainan terlebih dahulu.

6) Siswa bermain TTS.

7) Kelompok yang memenangkan permainan ini mendapatkan award dan kelompok

\section{Pengamatan} yang kalah mendapatkan hukuman sesuai dengan peraturan yang telah disepakati.

Hasil pengamatan dari observer selama proses pembelajaran siklus II adalah siswa pada waktu menerima pelajaran memperhatikan penjelasan yang diberikan oleh guru dengan baik. Berpartisipasi dalam kegiatan pembelajaran, sudah ada keinginan untuk mencari penelesaian soal dari guru. Mau bertanya jika ada kesulitan, dan mulai berani untuk mengerjakan didepan walaupun belum bisa. Sedang pengamatan yang diperoleh observer kepada guru yang mengajar adalah guru sudah mempersiapkan rencana pembelajaran dengan baik, metode yang digunakan sudah tepat, pemberian motivasi sudah cukup tapi masih ada beberapa kekurangan tidak menanyakan kepada siswa tentang kesulitan apa yang diperoleh dari materi yang diajarkan.

\section{Refleksi}

Setelah melakukan beberapa perbaikan yaitu perbaikan pembelajaran pra siklus, siklus I dan siklus II. Peneliti menyadari betul kekurangan - kekurangan pada proses pembelajaran mata pelajaran Matematika dengan materi bangun ruang pada siklus II. Walaupun peneliti sudah mempersiapkan proses pembelajaran sebaik mungkin, tetapi tetap masih ada kekurangannya diantaranya guru kurang memberi pertanyaan kepada siswa. Dari hasil refleksi yang dilakukan tersebut teman sejawat selaku observator juga menemukan beberapa kekurangan yaitu guru tidak memberi bimbingan kepada siswa yang belum jelas atau memahami materi pelajaran.

Keberhasilan dan kegagalan pada siklus II antara lain:

1) Keberhasilan

a) Hasil evaluasi belajar siswa meningkat.

b) Sebagian besar siswa sudah memahami materi.

c) Siswa sudah berani maju mengerjakan soal.

d) Siswa sudah berani untuk mengajukan pertanyaan.

2) Kegagalan

a) Masih ada 1 orang siswa yang belum mencapai tingkat ketuntasan.

b) Pengelolaan kelas masih kurang.

c) Masih ada beberapa siswa yang pada saat pelajaran berlangsung masih belum bisa terlibat aktif.

\section{Perbaikan Hasil Penelitian Perbaikan Pembelajaran}

1. Rekapitulasi prestasi Belajar Siswa dari Prasiklus sampai Sikls II 
Berdasarkan hasil observasi dan analisis yang telah dilaksanakan dari pra siklus sampai siklus II dapat dilihat dalam bentuk tabel rekapitulasi kegiatan per siklus sebagai berikut:

Tabel 4. Rekapitulasi Hasil Belajar Siswa

\begin{tabular}{|c|c|c|}
\hline No & Siklus & Rata-rata \\
\hline 1 & Prasiklus & $\mathbf{5 0}$ \\
\hline 2 & I & $\mathbf{6 0 , 7 0}$ \\
\hline 3 & II & $\mathbf{7 5 , 3 5}$ \\
\hline
\end{tabular}

Berdasarkan tabel tersebut dari hasil penelitian menunjukkan bahwa, penerapan model pemebelajaran coperative learningpada setiap siklus menunjukkan peningkatan yang sangat berarti, artinya hasil belajar siswa yang dilaksanakan pada akhir siklus mencapai ketuntasan minimum yang telah di tentukan.

Persentase Prestasi Belajar Siswa dari Prasiklus sampai Sikls II

Berdasarkan hasil observasi dan analisis yang telah dilaksanakan dari pra siklus sampai siklus II jika dipersentasekan dapat dilihat dalam bentuk tabel rekapitulasi kegiatan per siklus sebagai berikut:

Tabel 5. Persentase Ketuntasan Hasil Evaluasi Matematika

\begin{tabular}{|c|c|c|}
\hline No & Siklus & Persentase \\
\hline 1 & Pra Siklus & $12,90 \%$ \\
\hline 2 & Siklus I & $29,03 \%$ \\
\hline 3 & Siklus II & $90,32 \%$ \\
\hline
\end{tabular}

Berdasarkan tebel di atas, hasil belajar mengalami peningkatan dari tiap siklusnya, ini berarti bahwa penggunaan Metode dengan Model Pembelajaran Model STAD (Student Team Achievement Division) dalam pembelajaran Matematikapada konsep bangun ruang di kelas V SDN 39 Cakranegara telah dilaksnakan dengan baik dan mencapai hasil yang maksimal dan mecapai ketuntasan belajar.

\section{Kesimpulan dan Saran}

Berdasarkan hasil penelitian yang telah dilakukan dapat disimpulkan bahwa upaya meningkatkan hasil belajar siswa dengan metode Pembelajaran Model STAD (Student Team Achievement Division), telah mampu meningkatkan hasil belajar siswa. Peningkatan ini terjadi pada siklus I maupun siklus II dengan bukti adanya peningkatan pada:

1) Pelaksanaan pembelajaran konsep Matematika materi bangun ruang dengan menggunakan model Pembelajaran Model STAD (Student Team Achievement Division), dikelas V SDN 39 cakranegara terbukti dapat meningkatkan pemahaman siswa, hal ini berdasarkan hasil observasi terhadap aktivitas siswa dan jika dipersentasekan prasiklus $12,90 \%$, siklus $129,03 \%$, pada siklus 2 naik lagi menjadi $90,32 \%$.

2) Penerapan pembelajaran model STAD (Student Team Achievement Division) dalam materi bangun ruang di kelas V SDN 39 Cakranegara terbukti dapat meningkatkan hasil belajar siswa, hal ini dapat terlihat dari perolehan nilai rata-rata kelas dari hasil tes siswa pada setiap tahapan siklus semakin meningkat yaitu, nilai rata-rata kelas pada prasiklus sebesar 50, pada siklus I sebesar 60,70 dan pada siklus II sebesar 75,35 . 


\section{Saran}

Berdasarkan hasil penelitian ini, ada beberapa saran yang dapat disampaikan yakni; (1) Guru sebaiknya mengusahakan media pembelajaran benda-benda konkret yang berada disekitar siswa dapat menghilangkan verbalisme dan menyenangkan. (2) Guru harus memberi motivasi dan bimbingan pada siswa yang mengalami kesulitan. (3) Guru hendaknya menciptakan suasana belajar yang menyenangkan. (4) Siswa perlu dilatih untuk bergaul dan bekerjasama yang harmonis dalam kelompoknya dengan kegiatan yang positif. Oleh karena itu bekerja dalam kelompok untuk menyelesaikan tugas tertentu merupakan cara yang efektif untuk melatih sifat social pada siswa.

\section{Daftar Pustaka}

Arifin, Anwar. (2003). Memahami Paradigma Baru Pendidikan Nasional dalam UU Sisdiknas. Jakarta : Depag

Aini, H. (2019). UPAYA MENINGKATKAN HASIL BELAJAR MENGGUNAKAN ALAT PERAGA (ABP) DAN METODE PEMBELAJARAN YANG BERVARIASI PADA MATA PELAJARAN MATEMATIKA DAN BAHASA INDONESIA. Jurnal Teknologi Pendidikan, O(2), 94-100. Retrieved from http://ojs.ikipmataram.ac.id/index.php/jtp/article/view/1243

Basrowi, Suwandi. (2008). Prosedur Penelitian Tindakan Kelas . Bogor : Ghalia Indonesia.

Burengge, S. (2020). Penerapan Model Pembelajaran Kooperatif Tipe STAD dengan Pendekatan Kontekstual bagi Siswa SDN 7 Tentena Sulawesi Tengah. Jurnal Paedagogy, 7(4), 275-280. doi:https://doi.org/10.33394/jp.v7i4.2832

Depdiknas. (2008). Kurikulum Kelas V SD . Jakarta : Depdiknas.

Depdiknas. (2008). Peraturan Menteri Pendidikan Nasional. Jakarta : Depdiknas

Isjoni. (2009). Pembelajaran Kooperatif . Yogyakarta :Penerbit Pustaka Pelajar

Iskandar. (2009). Penelitian Tindakan Kelas . Ciputat : Gaung Persada

Israil, I. (2019). Implementasi Model Pembelajaran Cooperative Learning Tipe STAD untuk Meningkatkan Motivasi Belajar Siswa dalam Pembelajaran IPA di SMP Negeri 1 Kayangan. Jurnal Kependidikan: Jurnal Hasil Penelitian dan Kajian Kepustakaan di Bidang Pendidikan, Pengajaran dan Pembelajaran, 5(2), 117-123. doi:https://doi.org/10.33394/jk.v5i2.1807

Jayadi, A. (2017). PERBEDAAN PRESTASI BELAJAR SISWA YANG TIDAK MENGGUNAKAN METODE DISKUSI KELOMPOK DENGAN YANG MENGGUNAKAN PADA MATA PELAJARAN MATEMATIKA. Jurnal Teknologi Pendidikan, 2(2), 1-5. $\quad$ Retrieved from http://ojs.ikipmataram.ac.id/index.php/jtp/article/view/585

Karso. 2007. Pendidikan Matematika I . Jakarta : Universitas Terbuka.

Khafid, M. Suyati. (2002). Pelajaran Matematika Penekanan pada Berhitung 5. Yogyakarta : Penerbit Erlangga.

Gatot Muhsetyo. (2009). Pembelajaran Matematika SD . Jakarta : Universitas Terbuka.

Purwati, N. (2019). Upaya Meningkatkan Motivasi dan Hasil Belajar IPA Siswa Melalui Penerapan Model Pembelajaran STAD di Kelas Vi SD Negeri 42 Mataram. Jurnal Paedagogy, 6(1), 14-19. doi:https://doi.org/10.33394/jp.v6i1.2525

Ruseffendi, E.T. (1988). Pengajaran Matematika Modern dan Masa Kini Seri Pertama . Bandung : Tarsito.

Soenarjo. (2008). Matematika IV . Jakarta : Pusat Pembukuan, Depdiknas. 
Surya, Mohamad. (2005). Psikologi Pembelajaran dan Pengajaran . Jakarta : Pustaka Bani Quraisy

Surya, Muhammad. (2007). Dasar-Dasar Kependidikan di SD. Jakarta : Universitas Terbuka. Yuliati, G. (2018). Peningkatan Hasil Belajar Matematika Siswa Kelas XI IPA 3 SMA Negeri 1 Batukliang Melalui Penggunaan Model Pembelajaran Student Teams Achievement Division. Jurnal Kependidikan: Jurnal Hasil Penelitian dan Kajian Kepustakaan di Bidang Pendidikan, Pengajaran dan Pembelajaran, 4(1), 31-40. doi:https://doi.org/10.33394/jk.v4i1.899 